\title{
Water, energy and agricultural landuse trends at Shiroro hydropower station and environs
}

\author{
Olubunmi Adegun, Olalekan Ajayi, Gbolahan Badru, and Shakirudeen Odunuga \\ Department of Geography, University of Lagos, Lagos, Nigeria \\ Correspondence: Olubunmi Adegun (oadegun@unilag.edu.ng)
}

Received: 14 June 2017 - Accepted: 26 July 2017 - Published: 1 February 2018

\begin{abstract}
The study examines the interplay among water resources, hydropower generation and agricultural landuse at the Shiroro hydropower station and its environs, in north-central Nigeria. Non-parametric trend analysis, hydropower footprint estimation, reservoir performance analysis, change detection analysis, and inferential statistics were combined to study the water-energy and food security nexus. Results of Mann-Kendall test and Sen's slope estimator for the period 1960 to 2013 showed a declining rainfall trend at Jos, around River Kaduna headwaters at $-2.6 \mathrm{~mm} \mathrm{yr}^{-1}$, while rainfall at Kaduna and Minna upstream and downstream of the reservoir respectively showed no trend. Estimates of hydropower footprint varied between 130.4 and $704.1 \mathrm{~m}^{3} \mathrm{GJ}^{-1}$ between 1995 and 2013. Power generation reliability and resilience of the reservoir was 31.6 and $38.5 \%$ respectively with year 2011 being the most vulnerable and least satisfactory. In addition to poor reliability and resilience indices, other challenges militating against good performance of hydropower generation includes population growth and climate change issues as exemplified in the downward trend observed at the headwaters. Water inflow and power generation shows a weak positive relationship with correlation coefficient $(r)$ of 0.48 , indicating less than optimal power generation. Total area of land cultivated increased from $884.59 \mathrm{~km}^{2}$ in 1986 prior to the commissioning of the hydropower station to $1730.83 \mathrm{~km}^{2}$ in 2016 which signifies an increased contribution of the dam to ensuring food security. The reality of reducing upstream rainfall amount coupled with high water footprint of electricity from the reservoir, therefore requires that a long term roadmap to improve operational coordination and management have to be put in place.
\end{abstract}

\section{Introduction}

The interdependence of water, food and energy are widely recognised as important drivers of socioeconomic development. The importance of these natural resources are embedded in the United Nations (UN) 2030 Agenda for Sustainable Development Goals (SDG) 2, 6, 7 (UN SDG Report, 2016; ICSU-ISSC, 2015). With Nigeria's population expected to increase to 262, 599000 by 2030 (UNDESA, 2015), the country faces a great challenge of meeting these goals. For example, energy demand in the country averages $7 \%$ per year, with an estimated increase in demand for years 2000 and 2012 which is put at 14 and 37 TWh respectively, and estimates for 2020, 2030 and 2040 put at 68, 146 and 291 TWh. Similarly, this challenge may become more glaring with more than 90 million people not having access to grid electricity in Nigeria, yet the widespread use of back-up genera- tors has further reduced the number of people without access to any form of electricity significantly (IEA, 2014).

The link between the food-water-energy nexus and climate, especially rainfall in the study area greatly influences water availability, agricultural production, and electricity generation and supply, in the long run. For instance, high inter-annual variability and marked seasonality of rainfall, coupled with episodes of streamflow drought, have often resulted in reduced power production of hydropower stations in the country owing to low gauge height level, while excessive rainfall sometimes results in downstream flooding with dire consequences especially for the cultivated lands.

Furthermore, the location of the country's hydropower stations in the savannah region suggests that a high volume of water will be lost through evaporation hence the need to know the water footprint of these reservoirs. 
A number of approaches have been used to estimate the footprint of hydropower reservoirs in different parts of the world. Bueno et al. (2016) used the conventional gross water footprint method for the Camargos Hydropower Reservoir in Brazil, and reported that the average hydropower footprint in Brazil exceeded the global average. Herath et al. (2011) estimated the hydropower footprint of all major hydropower reservoirs in New Zealand using a combination of the consumptive water use method, the net consumptive water use method, and the net water balance method.

Zhao and Liu (2015) developed a method that utilises an allocation coefficient to allocate water footprint among the different ecosystem services offered by the Three Gorges Reservoir in China. The study also compared the estimates of the water footprint obtained with the values derived from estimation based on the gross water footprint method. The result of the study showed that the gross water footprint method over-estimated the hydropower footprint. Mekonen and Hoekstra (2012) employed the gross water footprint method to estimate the hydropower footprint of 35 selected hydropower reservoirs in different parts of the world. The study revealed that hydropower reservoirs located in Ghana, Mozambique, Zambia, Zimbabwe, and Kenya all had high hydropower footprint, with Akosobo-Kpong reservoirs having the highest value globally.

In evaluating the performance of water resources systems, Hashimoto et al. (1982) used three indices; reliability, resilience and vulnerability to evaluate the performance of a water resources system. The indices have also been used to assess water resources systems performance under different prevailing natural and operational conditions. For example, Longobardi et al. (2014) used the 3 indices to assess the performance of a multi-purpose dam in southern Italy under conditions of climate variability. Gohraian et al. (2016) used the 3 performance indices in combination with a hydrological model, a water system model and climate change projections in a study of the Salt Lake City's water supply system under climate change conditions. In a study by Raje and $\mathrm{Mu}-$ jumdar (2010) the reliability index was used to evaluate the performance of a reservoir in Orissa, India, with respect to hydropower generation, irrigation and flood control. The indices of resiliency and vulnerability were used to assess the system's performance in relation to hydropower generation only.

With respect to the performance of the Shiroro Hydropower facility as a water resources system, only a few studies exist in the literature. This include a study by Sule (1988), in which the future operations and performance of the reservoir system which was still under construction were simulated under different operating scenarios using a combination of Probabilistic Dynamic Programming Optimisation Model and the indices of reliability, resilience and vulnerability. The result of the scenario simulation showed severe and frequent failures at the $70 \%$ plant factor recommended for Nigeria. Based on this result, it was concluded that reservoir operations should be carried out at 40 to $50 \%$ power plant factor. Similarly, a recent study by Gbadamosi et al. (2015), which analysed the performance and efficiency of the Shiroro Hydropower Station using the plant availability factor, the capacity factor and the overall efficiency factor, showed that the capacity factor of the hydropower system varied between 23.5 and $50.7 \%$ compared with internationally benchmark of $80 \%$.

With regards to the estimation of water footprint in the studies highlighted above, hydropower generation was shown as a large consumer of water, and the method, a veritable indicator of resource use. The general output from the review of studies on water resources systems performance indicated that the 3 indices are useful tools in the description of the frequency and duration of system failure and recovery. The studies also showcase how the indices can serve as a basis for the improvement of the operations and management of different water resources infrastructures and systems.

Considering the importance of the Shiroro hydropower station in the water-energy and its food security interconnections within the River Kaduna catchment, and indeed the county at large, there is a need to have a better understanding of the drivers and feedback mechanisms at play. To achieve this therefore, this study utilises a combination of statistical analyses, hydropower water footprint estimation based on the gross water footprint method, water resources systems performance indices evaluation and change detection analysis.

\section{Study area}

The Shiroro Hydropower reservoir is a storage based hydroelectric facility (Fig. 1) located in the Shiroro Gorge approximately between latitude $9^{\circ} 46^{\prime} 35.29^{\prime \prime}$ and $10^{\circ} 08^{\prime} 36.65^{\prime \prime} \mathrm{N}$ and longitude $6^{\circ} 50^{\prime} 51.23^{\prime \prime}$ and $6^{\circ} 53^{\prime} 14.53^{\prime \prime} \mathrm{N}$. It is located approximately $90 \mathrm{~km}$ southwest of Kaduna, on River Dinya. The facility has an installed capacity of $600 \mathrm{MW}$ (Kolo, 1996). The reservoir has a surface area of about $320 \mathrm{~km}^{2}$, a maximum length of $32 \mathrm{~m}$ and a total storage capacity of 7 billion $\mathrm{m}^{3}$ (Suleiman and Ifabiyi, 2015).

About $70 \%$ of inflows into the reservoir is from River Kaduna, with lateral contributions from Rivers Dinya, Sarkin-Pawa, Erena and Muyi (Adie et al., 2012; Eze, 2006). The reservoir is located in the River Kaduna catchment in the Guinea Savanna zone of the country, between the semiarid climate of the north and the sub-humid climate of the south. The climate of the catchment is consistent with the rest of the country. Rainfall in the area is controlled by the tropical maritime (mT) air mass. During the dry season the area is dominated by the tropical continental (cT) air mass (Anyadike, 1993; Iloeje, 2009). The dry season is between the month of November and March, while the rainy season commences in April or May and lasts till October, (Jimoh and Ayodeji, 2003). Average annual rainfall in the catchment is about $1204.91 \mathrm{~mm}$, with an average of about 110 days per 


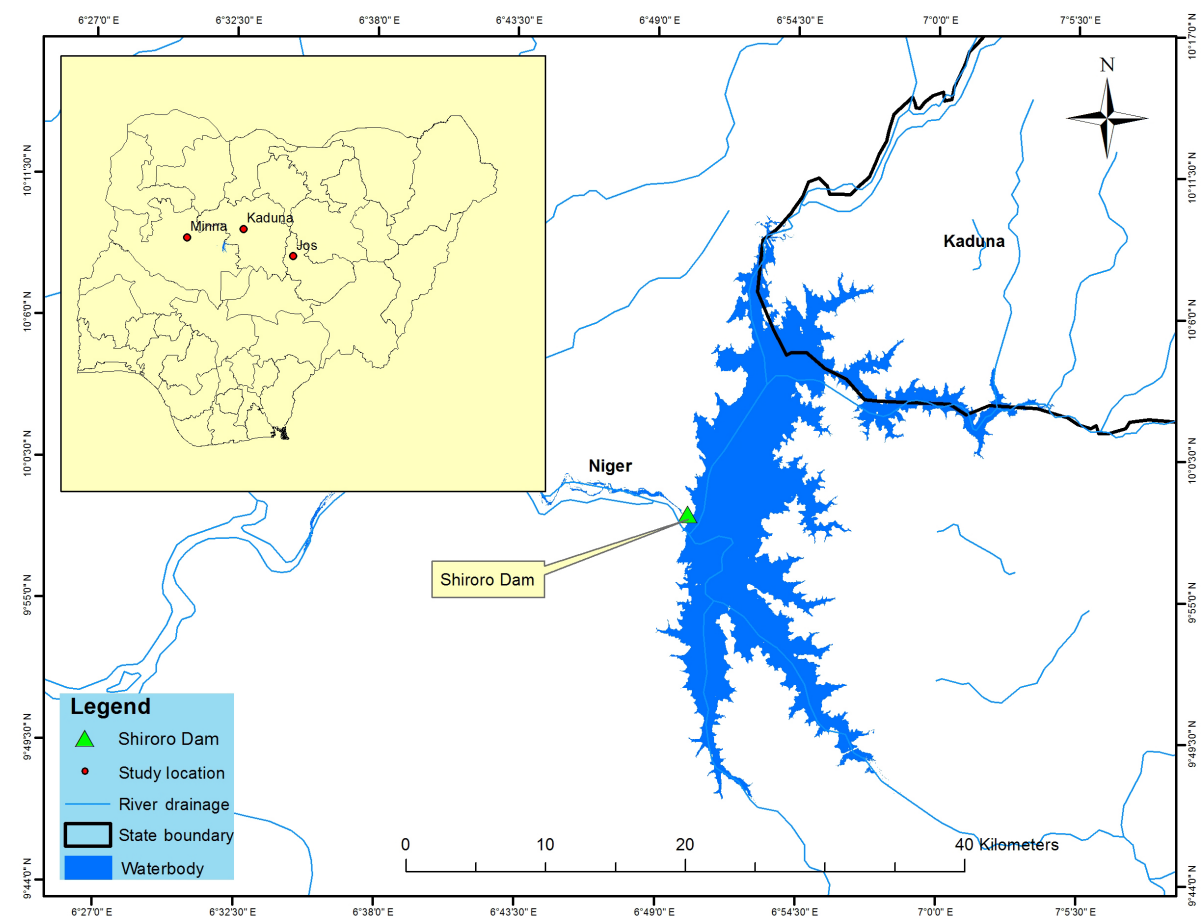

Figure 1. Location of Shiroro hydropower dam.

year receiving a rainfall amount of $0.1 \mathrm{~mm}$ (Okafor et al., 2017). Annual temperature around the reservoir varies between 27 and $35^{\circ} \mathrm{C}$ (Suleiman and Ifabiyi, 2015).

\section{Methodology}

Historical monthly rainfall data for locations within the catchment, Jos, Kaduna and Minna for 1960 to 2013 was obtained from the Nigerian Meteorological Agency (NIMET). Monthly data on inflow, turbine discharge, reservoir evaporation and energy generated for 1995 to 2013 was obtained from the Shiroro Hydropower Station.

To establish the presence or absence of trend in rainfall within the catchment, a Mann-Kendall trend test was carried out in XLSTAT. The Mann-Kendall test statistic is expressed as:

$Z_{c} \begin{cases}\frac{S-1}{\sqrt{\operatorname{var}(S)}}, & S>0 \\ 0 & S=0 \\ \frac{S+1}{\sqrt{\operatorname{var}(S)}}, & S<0\end{cases}$

in which

$S=\sum_{i=1}^{n-1} \sum_{k=i+1}^{n} \operatorname{sgn}\left(x_{k}-x_{i}\right)$

where $x_{k}, x_{j}$ are the sequential data values, $n$ is the length data set, and $\operatorname{sgn}(\theta)$ is equal to $1,0,-1$ if $\theta$ is greater than, equal to, or less than zero, respectively. The Sen's slope estimator is expressed as:

$\beta=\operatorname{Median}\left(\frac{x_{i}-x_{j}}{i-j}\right), \quad \forall j<i$

in which $1<j<I<n$. $\beta$ is the median overall combination of the record pairs for the whole dataset, and therefore resistant to extreme observation or outliers. A positive value of the $\beta$ indicates a slope of an upward trend and a negative value represents a downward trend (Machiwal and Jha, 2012).

The water footprint of electricity from hydropower generation was estimated based on Mekonnen and Hoekstra (2012). This is expressed as:

$\mathrm{WF}=\frac{\mathrm{WE}}{\mathrm{EG}}$.

The total volume of water evaporated (WE, $\mathrm{m}^{3} \mathrm{yr}^{-1}$ ) from the reservoir on an annual basis is expressed in Eq. (5) as:

$\mathrm{WE}=\left(10 \times \sum_{t-1}^{365} E\right) \times A$.

The system performance evaluation of the hydropower station was based on Hashimoto et al. (1982). The 3 indices of system performance, reliability, resilience and vulnerability are stated in Eq. (6)-(8) respectively as:

$r_{\mathrm{t}}=1-\frac{f_{\mathrm{p}}}{n} 0 \leq r_{\mathrm{t}} \leq 1, \quad f_{\mathrm{p}} \leq n$ 
Table 1. Data sources and characteristics.

\begin{tabular}{lclcc}
\hline Data & Year & Instrument & Resolution & Source \\
\hline LANDSAT TM & 1985 & Thematic Mapper 7, 4, 2 bands & $30 \mathrm{~m}$ & USGS, glovis.org \\
LANDSAT ETM & 2002 & Enhanced TM-7, 4, 2 bands & $30 \mathrm{~m}$ & \\
LANDSAT ETM & 2016 & OLI-7, 5, 3 bands & $30 \mathrm{~m}$ & \\
\hline
\end{tabular}

Table 2. Result of Mann-Kendall trend test.

\begin{tabular}{lcccc}
\hline Location & $\begin{array}{c}\text { Kendall's } \\
\text { Tau }\end{array}$ & $P$-value & $\begin{array}{c}\text { Level of } \\
\text { significance }\end{array}$ & $\begin{array}{c}\text { Sen's slope } \\
\left(\mathrm{mm} \mathrm{yr}^{-1}\right)\end{array}$ \\
\hline Jos & -0.185 & 0.048 & 0.05 & -2.609 \\
Kaduna & -0.102 & 0.279 & 0.05 & -0.824 \\
Minna & -0.049 & 0.601 & 0.05 & -1.554 \\
\hline
\end{tabular}

where $f_{\mathrm{p}}$ is the number of failure periods out of a total of $n$ periods.

The resilience of a system denoted by $\Upsilon_{\text {mean }}$ describes how quickly a system is likely to recover from an unsatisfactory state or failure event. If $d_{j}$ is the duration of each failure or unsatisfactory state, then resilience can be expressed as:

$\left[\frac{1}{N} \sum_{j=1}^{N} d_{j}\right]-1$

Vulnerability $V_{\text {mean }}$ is a measure of the extent of failure which in this study is the maximum value of shortfall among the values of unsatisfactory period. If $X_{t}$ is the system performance variable (annual inflow for power generation) and $X_{0}$ is the threshold value (mean long term inflow for power generation), the value for each unsatisfactory period can be computed as:

$V_{j} \sum_{t=1}^{d_{j}}\left[X_{t}-X_{0}\right]$

and vulnerability ( $\left.V_{\text {mean }}\right)$ calculated according to Kjelsen and Rosberg (2004) as:

$V_{\text {mean }}=\frac{1}{N} \sum_{j=i}^{N} v_{j}$.

The degree of relationship between inflow into the reservoir and power generated, and between rainfall and reservoir inflow was determined using Pearson correlation coefficient, expressed as:

$r=\sum x y / N \sigma_{x} \sigma_{y}$

where $r$ is the correlation coefficient, $x$ and $y$ are data variables under consideration, and $\sigma_{x}$ and $\sigma_{y}$ are standard deviation of the variables under consideration.

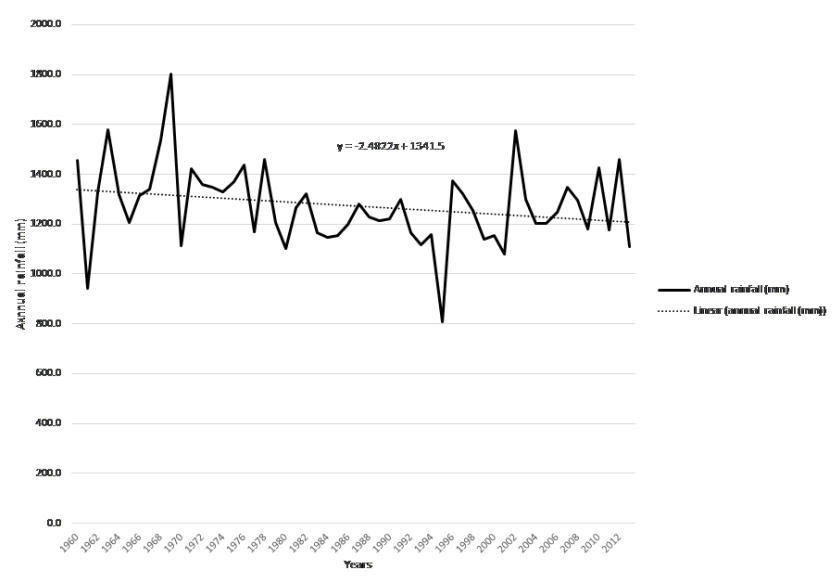

Figure 2. Trend of annual rainfall at Jos.

The USGS Landuse Classification model was used to determine the landuse change characteristics around the Shiroro Dam in three progressive scenarios: 1986, 2000 and 2016. This is done through the remote sensing technique (Table 1) using analytical tool of ENVI. This landuse adopted a pragmatic hierarchical land use classification scheme where seven major landuse classes were identified. About 1000 pixels of training dataset were randomly sampled from the spectral signature of each of the classes to define their respective land use/land cover type. In addition, the Maximum Likelihood classifier was used to extract these classes of landuse. Analysis was based on area calculation for the three static years (1986-2000 and 2000-2016).

\section{Results and discussion}

\subsection{Rainfall trend and rainfall-reservoir inflow relationship}

The results of the Mann-Kendall trend test for the rainfall trend (Table 2) shows that the computed $p$-value for Jos (Fig. 2) is lower than the significance level, $\alpha=0.05$, therefore the alternative hypothesis $\left(H_{1}\right)$ of the existence of trend in the time series was accepted. The result of the Sen's slope estimator $(Q)$ also indicates a statistically significant downward trend at a declining rate of $-2.6 \mathrm{~mm} \mathrm{yr}^{-1}$. This shows that rainfall around the headwaters of River Kaduna at Kangimi Hills in the Jos Plateau has been experiencing a declining trend. According to Olaniran (2002), negative rain- 
Table 3. Annual water footprint of Shiroro hydropower reservoir between 1995 and 2013.

\begin{tabular}{lllllllll}
\hline Year & 1995 & 1996 & 1997 & 1998 & 1999 & 2000 & 2001 & 2002 \\
\hline $\begin{array}{l}\text { WFP } \\
\left(\mathrm{m}^{3} \mathrm{GJ}^{-1}\right)\end{array}$ & 668.0 & 431.6 & $\mathrm{NA}^{*}$ & 384.6 & $\mathrm{NA}^{*}$ & 468.1 & 328.4 & 489.1 \\
\hline Year & 2003 & 2004 & 2005 & 2006 & 2007 & 2008 & 2009 & 2010 \\
\hline $\begin{array}{l}\text { WFP } \\
\left(\mathrm{m}^{3} \mathrm{GJ}^{-1}\right)\end{array}$ & 368.9 & 340.6 & 704.1 & 130.4 & 320.5 & 348.9 & 341.2 & 353.6 \\
\hline Year & 2011 & 2012 & 2013 & & & & & \\
\hline $\begin{array}{l}\text { WFP } \\
\left(\mathrm{m}^{3} \mathrm{GJ}^{-1}\right)\end{array}$ & 297.0 & 281.5 & 269.3 & & & & & \\
\hline
\end{tabular}

$\mathrm{NA}^{*}=$ not available.

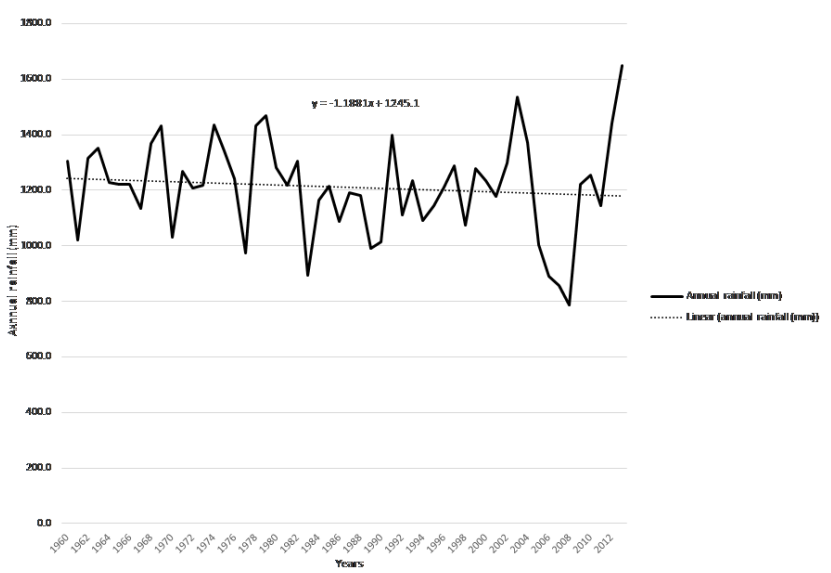

Figure 3. Trend of annual rainfall at Kaduna.

fall trends in parts of Nigeria is owing to an early retreat of rainfall and a decline in the number of rain days at the end of the rainy season. The implication of this is a gradual reduction of surface runoff and discharge of River Kaduna over the course of the study period. This can consequently lead to the inability of the hydropower reservoir to be filled to its maximum pool elevation because of the reduced inflow contribution to the reservoir, leading to the disruption of normal reservoir operations and hence hydropower generation (Oladipo, 1994). Declining rainfall trend upstream of the dam also means that the volume of tail race discharges available for downstream uses, especially in the dry season will be significantly reduced.

For Kaduna and Minna (Figs. 3 and 4) representing locations along the middle and lower course of the River, the computed $p$-value was greater than the level of significance, hence the acceptance of the null hypothesis $\left(H_{0}\right)$ of none existence of trend in the time series. The results indicate a weak and statistically insignificant trend over time. The $Q$ values of -1.55 and $-0.8 \mathrm{~mm} \mathrm{yr}^{-1}$ for Kaduna and Minna respectively also suggest that the declining annual rainfall is not

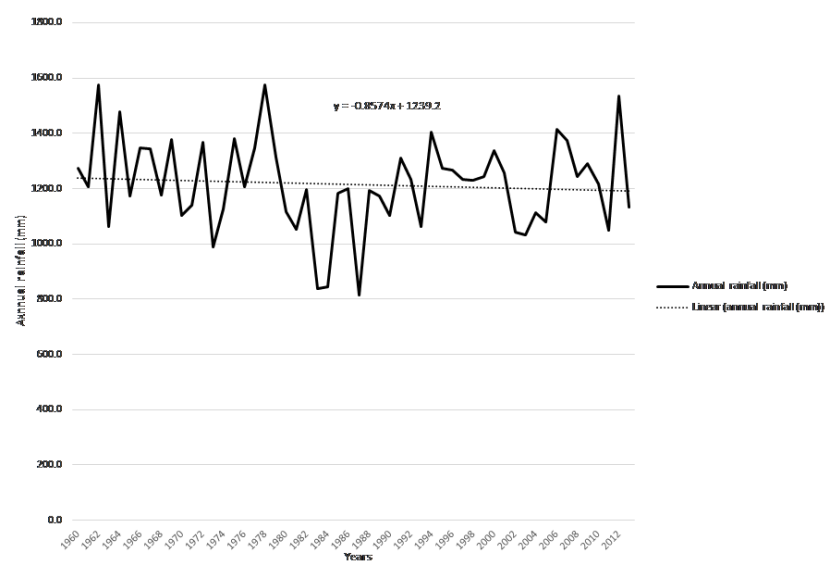

Figure 4. Trend of annual rainfall at Minna.

statistically significant. The generally declining annual rainfall at the headwater region portends negative consequences for hydropower generation, water supply, rain-fed and irrigated agriculture, and hence food security.

The result of the Karl Pearson correlation coefficient $(r=0.85)$ for catchment rainfall-reservoir inflow relationship shows a high degree of positive relationship. This results shows the strong linkage that exist between rainfall in the catchment and inflow into the reservoir. This suggests that the lower the amount of rainfall available, the lesser the reservoir inflow and stage height, and the lesser the capacity of the capacity of installed turbines to generate power.

\subsection{Hydropower water footprint}

The water footprint of electricity from the hydropower station for the period 1995 to 2013, (Table 3) varied between $130.4 \mathrm{~m}^{3} \mathrm{GJ}^{-1}$ (year 2006) and $704.1 \mathrm{~m}^{3} \mathrm{GJ}^{-1}$ (year 2005), while the average footprint was $383.91 \mathrm{~m}^{3} \mathrm{GJ}^{-1}$. This implies that the highest consumptive use of water via evaporation from the Shiroro reservoir occurred in 2005, while the 
Table 4. Landuse change analysis.

\begin{tabular}{lrrrrrrrr}
\hline & \multicolumn{2}{c}{1986} & & \multicolumn{2}{c}{2000} & & \multicolumn{2}{c}{2016} \\
\cline { 2 - 3 } Landuse & Area $\left(\mathrm{km}^{2}\right)$ & $\%$ & & Area $\left(\mathrm{km}^{2}\right)$ & $\%$ & & Area $\left(\mathrm{km}^{2}\right)$ & $\%$ \\
\hline Built-up & 211.93 & 4.2 & & 232.95 & 4.8 & & 252.01 & 5.5 \\
Sandy shore & 1.07 & 0.5 & & 0.7 & 0.3 & & 0.25 & 0.1 \\
Fallow land & 1709.9 & 37.6 & & 1541.46 & 33.9 & & 1069.75 & 23.6 \\
Farming & 884.59 & 19.5 & & 1142.03 & 25.2 & & 1730.83 & 38.1 \\
Ridge & 439.93 & 9.7 & & 438.63 & 9.7 & & 438.14 & 9.6 \\
Savanna/Orchard bush & 1044.65 & 23 & & 934.09 & 20.6 & & 798.01 & 17.6 \\
Waterbody & 248.73 & 5.5 & & 250.74 & 5.5 & & 251.61 & 5.5 \\
\hline Total & 4540.6 & 100 & & 4540.6 & 100 & & 4540.6 & 100 \\
\hline
\end{tabular}

Source: Author's GIS Analysis.

lowest consumptive use occurred the following year, 2006. The coefficient of variation of the water footprint and evaporation was 36 and $25 \%$ respectively, while the coefficient of variation for electricity generated was $15 \%$. This suggests a moderate inter-annual variability in the water footprint, evaporation and energy generated from the hydropower station. Water footprint could not be computed for 1997 and 1999 due to the non-availability of data on electricity generated in both years.

As a large consumer of water, it is necessary for the decision makers to have an adequate knowledge of the water footprint of hydropower generation. This will help to forestall undesirable consequences the on downstream environmental flows and ensure sustainable management for electricity generation and other uses.

\subsection{Hydropower reservoir performance and inflow-power generation relationship}

The result of the reliability and resilience of the hydropower reservoir with respect to power generation are 31.6 and $38.5 \%$ respectively. This is an indication that the hydropower power system was less than reliable more than half of the time, which is also reflected in the low level of resilience as suggested by the low resilience value of $38.5 \%$. The system was at its most vulnerable and least satisfactory in 2011, with an annual inflow of $112000 \mathrm{~m}^{3}$. The result of the Pearson correlation coefficient $(r=0.48)$ shows a weak degree of positive relationship between inflow into the reservoir and power generated.

From these results it is obvious that the hydropower system performance is below the optimal level. However, the low performance of the hydropower system does not signify a lack of water in the reservoir, rather other operational deficiencies also contributed to the below optimal level of performance. These operational deficiencies include breakdown of equipment, inadequate maintenance, low level of inflow into the reservoirs, poor coordination and inefficient operating guidelines (Sule, 1988). In view of the current state of
Table 5. Statistics of area and yield of crops cultivated in Niger State (2011-2016).

\begin{tabular}{lrr}
\hline & Maize & Rice \\
\hline Minimum area $\left(10^{3} \mathrm{HA}\right)$ & 150.5 & 264.0 \\
Maximum area $\left(10^{3} \mathrm{HA}\right)$ & 355.3 & 513.6 \\
Average area $\left(10^{3} \mathrm{HA}\right)$ & 215.9 & 506.3 \\
Minimum yield $\left(10^{3} \mathrm{MT} \mathrm{HA}^{-1}\right)$ & 2.2 & 2.0 \\
Maximum yield $\left(10^{3} \mathrm{MT} \mathrm{HA}^{-1}\right)$ & 3.0 & 5.3 \\
Average yield $\left(10^{3} \mathrm{MT} \mathrm{HA}^{-1}\right)$ & 2.6 & 3.7 \\
\hline
\end{tabular}

Source: Niger State Agricultural and Mechanisation Development Authority (2017).

affairs, there is a need for an efficient reservoir operational strategy to reduce the system's vulnerability and improve the level of reliability and resilience.

\subsection{Landuse changes analysis}

Table 4 and Figs. 5 to 7 show the static distribution of the landuse/landcover pattern in three periodical scenarios of landuse dynamics around the Shiroro Dam Development Project in 1986, 2000 and 2016 respectively. Subsistence land area for crop production increased from $884.59 \mathrm{~km}^{2}$ in 1986 to $1730.83 \mathrm{~km}^{2}$ in 2016 . The significant gains in agricultural landuse in the area can be attributed to the construction of the dam, which although has no designed irrigation scheme but serves as a source of irrigation water for peasant farmers around the hydropower reservoir through self- effort. Crops cultivated in the area include yam, maize, guinea, corn, sugar cane, millet, beniseed, groundnut, rice, banana, plantain and cotton. Although there are no official records of the hectares of land devoted to the cultivation of these crops in the area, records for the whole of Niger State (Table 5), where the hydropower reservoir is located, shows that the area devoted to the cultivation of maize between 2011 and 2016 varied between 150.5 and 355.3 thousand hectares, with an average area of 215.9 thousand hectares while the area devoted to 


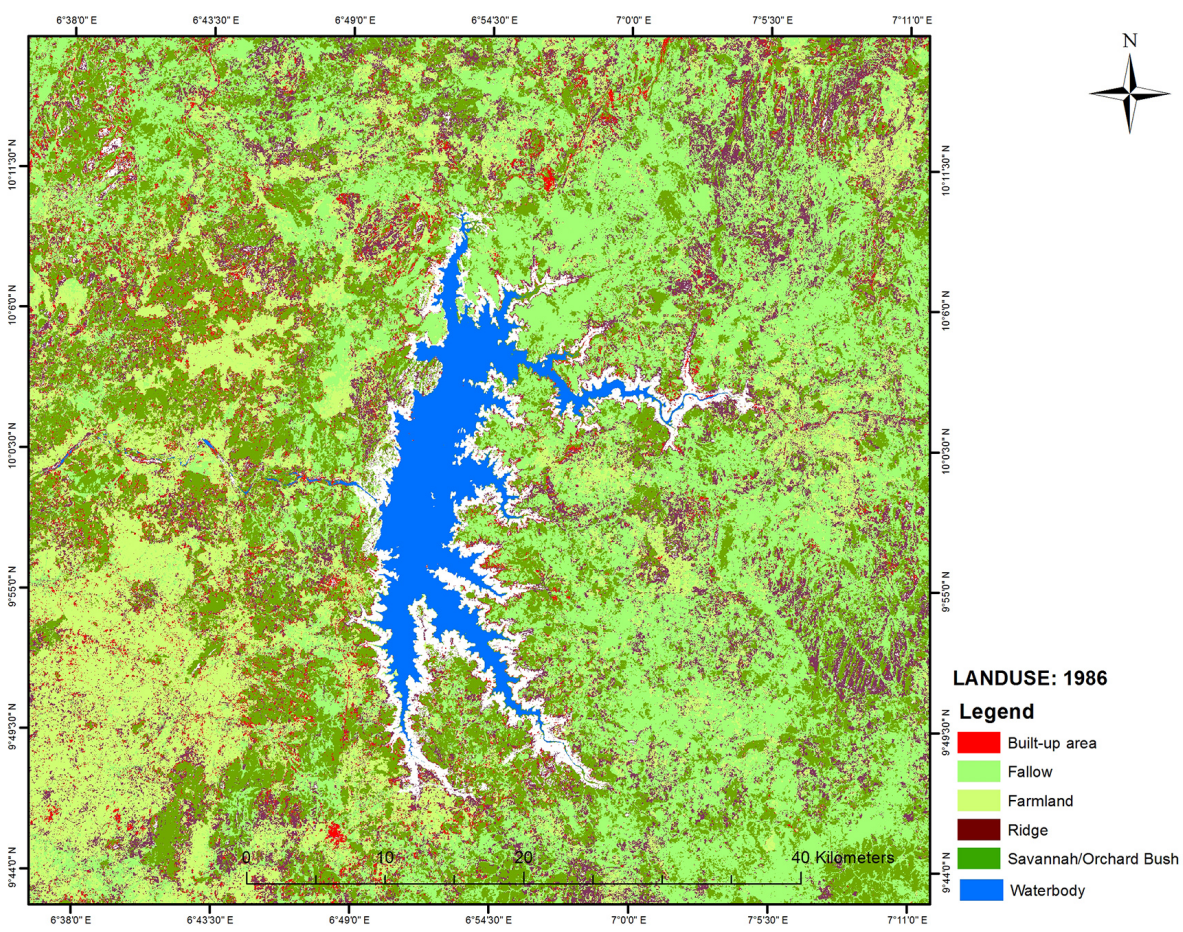

Figure 5. Landuse/landcover pattern in 1986.

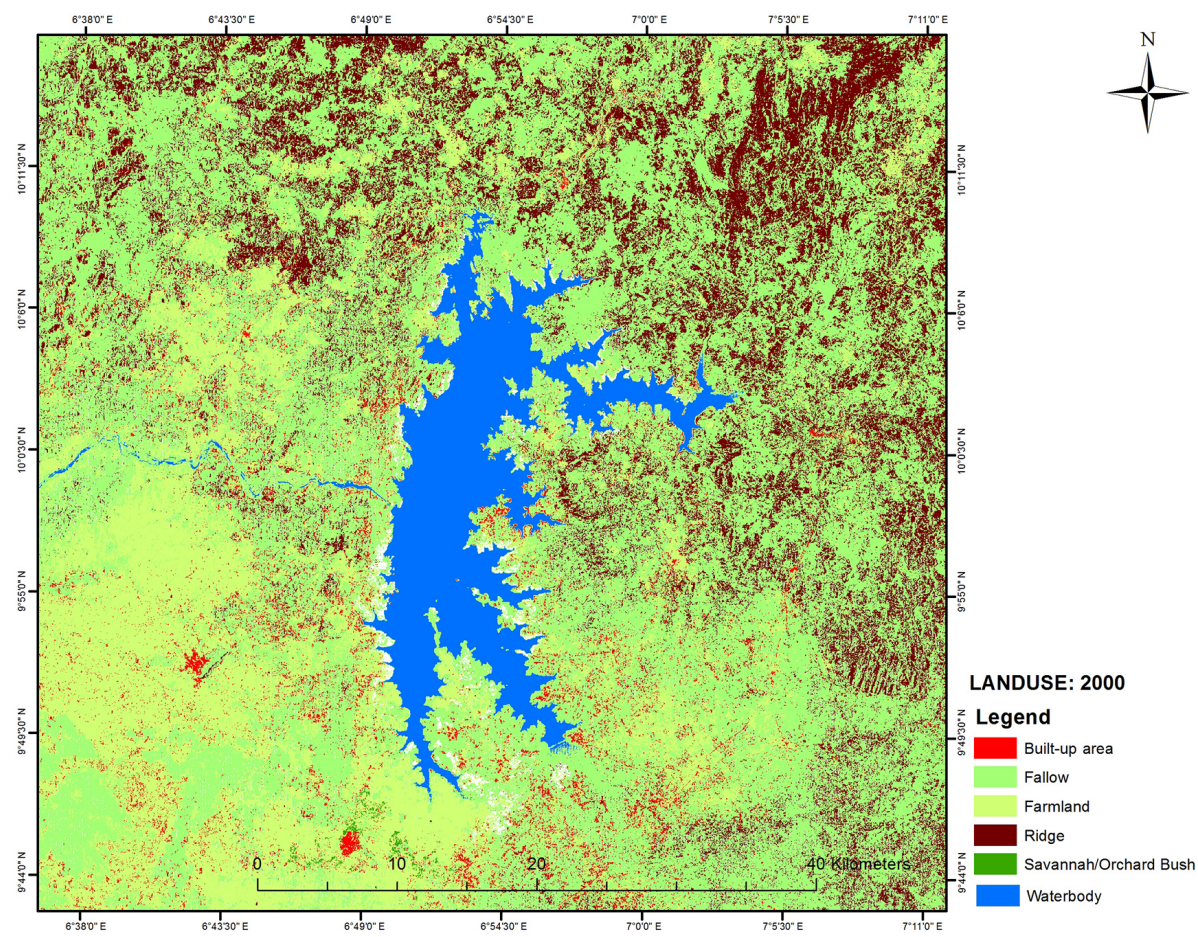

Figure 6. Landuse/landcover pattern in 2000.

rice varied between 264.0 and 513.6 thousand hectares, with an average areal extent of 506 thousand hectares. Maize yield for the same period varied between 2.2 and 3.0 thousand met- ric tonnes per hectare, with an average of 2.6 thousand metric tonnes per hectare, while rice yield varied between 2.0 


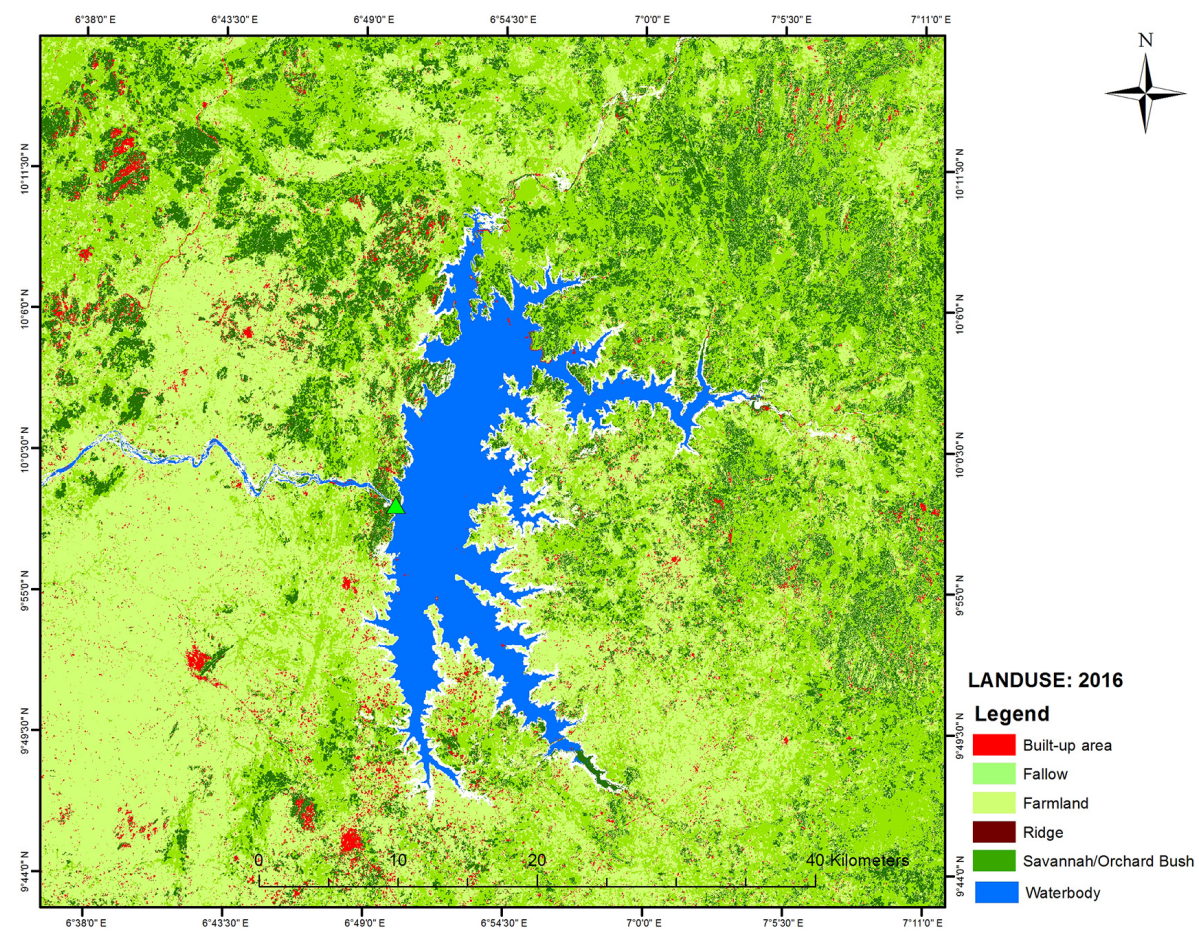

Figure 7. Landuse/landcover pattern in 1986.

and 5.3 thousand metric tonnes per hectare, with an average yield of 3.7 thousand metric tonnes per hectare.

Looking at the emergence of the hydropower facility and the trend of agricultural landuse in the area, the inter-play of water, energy and agricultural nexus in Shiroro can be deemed to have had a positive impact on the livelihood of the local populace and food security in the area and the country at large.

\section{Summary and conclusion}

The study showed how a combination of methods can be used to investigate feedback mechanisms operational at the food-water-energy nexus at the Shiroro hydropower station and its environs. Although the results of the reliability and resilience of the hydropower reservoir with respect to hydropower generation are below the average performance with less than $40 \%$ for all indices. The comparative gain in agricultural sector through water utilisation by peasant farmers actually provide an additional gain derived from the interplay of food-water-energy nexus. In the face of a reducing upstream rainfall amount coupled the with high water footprint of electricity from the reservoir, it is recommended that a long term roadmap to improve the operational coordination and management has to be put in place. Also, a formal irrigation scheme should be provided to strengthen agricultural production in the area.
Data availability. Links to the USGS Satellite Imagery data is available at Earth explorer http://earthexplorer.usgs.gov. The hydrometeorological and agricultural data is not publicly accessible.

Author contributions. OAd conceptualized and lead the team on this research. She also wrote the manuscript and effected the corrections during the write-up. OAj gathered and processed all the spatial data used for this article. GB assisted in the gathering of the hydrometeorological data used for the study. SO reviewed the write-up from time to time for necessarycorrections.

Competing interests. The authors declare that they have no conflict of interest.

Special issue statement. This article is part of the special issue "Water security and the food-water-energy nexus: drivers, responses and feedbacks at local to global scales". It is a result of the IAHS Scientific Assembly 2017, Port Elizabeth, South Africa, 10-14 July 2017.

Acknowledgements. The authors wish to express their profound gratitude to the following institutions. The Nigerian Meteorological Agency for the climatic data, the Shiroro Hydropower Station for the hydrological and power generation data, and the Niger State Agricultural and Mechanisation Development Authority for the agricultural yield data. 
Edited by: Barry Croke

Reviewed by: Mykhaylo Romashchenko and one anonymous referee

\section{References}

Adie, D. B., Ismail, A., Mohammed, M. M., and Aliyu, U. B.: Analysis of the water resources potential and useful life of Shiroro Dam, Nigeria, Niger. J. Basic Appl. Sci., 20, 341-348, 2012.

Anyadike, R. N. C.: Seasonal and annual rainfall variations over Nigeria, Int. J. Climatol., 13, 567-580, https://doi.org/10.1002/joc.3370130507, 1993.

Bueno, E. D., de Mello, C. R., and Alves, G. J.: Evaporation from Camargos hydropower plant reservoir, Brazil. J. Water Resour., 21, 570-575, 2016.

Eze, J. N.: Vulnerability and adaptation to climatic variability and extremes. A case study of flooding in Niger State, MSc dissertation, School of Geography and Environmental Studies, University of Witwatersrand, Witwatersrand, South Africa, $153 \mathrm{pp}$., 2006.

Gbadamosi, S. L., Ojo, O., Adedayo, O., and Nnaa, L.: Evaluation of operational efficiency of Shiroro hydroelectric plant in Nigeria, Int. J. Sci. Eng. Investigat., 4, 2251-8843, 2015.

Gohraian, E., Burian, S. J., Bardsley, T., and Strong, C.: Incorporating potential severity into vulnerability assessment of water supply systems under climate change conditions, J. Water Resour. Pl. Manage., 14, 1-12, 2016.

Hashimoto, T., Stedinger, J. R., and Loucks, D. P.: Reliability, resiliency and vulnerability criteria for water resource system performance evaluation, Water Resour. Res., 18, 14-20, 1982.

Herath, I., Deurer, M., Horne, D., Singh, R., and Clothier, B.: The water footprint of hydroelectricity: a methodological comparison from a case study in New Zealand, J. Clean Prod., 19, 15821589, 2011

ICSU-ISSC: Review of the sustainable development goals: the science perspective, Paris International Council for Science, Paris, 88 pp., 2015.

IEA - International Energy Agency: Africa energy outlook. A focus on energy prospects in Sub-Saharan Africa, World Energy Outlook Special Report, Paris, 237 pp., 2014.

Iloeje, N. P.: A New Geography of Nigeria, New Revised Edn., Longman Press, Lagos, Nigeria, 2009.

Jimoh, O. D. and Ayodeji, O. S.: Impact of the Gurara River (Nigeria) interbasin water transfer scheme on the Kaduna River at Shiroro dam, in: Water resources systems: Hydrological risk management and development, edited by: Blosch, G., Franks, S., Kumagai, M., Musiake, K., and Rosbjerg, D., Proceedings of Sapporo Symposium, July 2003, Sapporo, 277-286, 2003.
Kjelsen, T. R. and Rosberg, D.: Choice of reliability, resilience and vulnerability estimates for risk assessments of water resources systems, Hydrolog. Sci. J., 49, 755-767, 2004.

Kolo, R. J.: The assessment of physico-chemical parameters of shiroro lake and its major tributaries, edited by: Eyo, A. A., Proceedings of the 13th annual conference of fisheries society of Nigeria, 3-8 November 1996, New Bussa, Nigeria, 260-268, 1996.

Longobardi, A., Mautone, M., and De Luca, C.: Reservoirs performances under climate variability: a case study, Proceedings of the ICWRS2014, June 2014, Bologna, Italy, 526-531, 2014.

Machiwal, D. and Jha, M. K.: Hydrologic Time Series Analysis: Theory and practice, Capital Publishing, Dordrecht, the Netherlands, 2012.

Mekonnen, M. M. and Hoekstra, A. Y.: The blue water footprint of electricty from hydropower, Hydrol. Earth Syst. Sci., 16, 179187, https://doi.org/10.5194/hess-16-179-2012, 2012.

Niger State Agricultural and Mechanisation Development: Authority Report, Minna, Nigeria, 2017.

Okafor, G. C., Jimoh, O. D., and Larbi, K. I.: Detecting changes in hydro-climatic variables during the last four decades (19752014) on downstream Kaduna river catchment in Nigeria, Atmos. Clim. Sci., 7, 161-175, 2017.

Oladipo, E. O.: An indication of abrupt change of rainfall and its impacts on energy development in Nigeria, Proceedings of the International Workshop on Impacts of Climate Change in Energy Development, Jos, 231-238, 1995.

Olaniran, O. J.: Rainfall anomalies in Nigeria: The contemporary understanding, Inaugural Lecture, University of Ilorin, Ilorin, 2002.

Raje, D. and Mujumdar, P. P.: Reservoir performance under uncertainty in hydrologic impacts of climate change, Adv. Water Resour., 33, 312-326, 2010.

Sule, B. F.: Reservoir operation policies for optimising energy generation at shiroro dam, Water Resour. Manage., 2, 209-219, 1988.

Suleiman, Y. M. and Ifabiyi, I. P.: The role of rainfall variability in reservoir storage management at Shiroro hydropower dam, Nigeria, Monoma Ethiop. J. Sci., 7, 55-63, 2015.

UNDESA: World population prospects: the 2015 revision, key findings and advance tables, New York, 59 pp., 2015.

UN SDG - United Nations, Department of Economic and Social Affairs, Population Divison: The sustainable development goals report, United Nations Report, New York, 52 pp., 2016.

Zhao, D. and Liu, J.: A new approach to assessing the water footprint of hydroelectric power based on allocation of water foot print among reservoir ecosystem services, Phys. Chem. Earth, 79-82, 40-45, 2015. 